\title{
The Right to Work as a Fundemantal Human Right
}

\author{
Prof. Dr. Pir Ali Kaya, Labour Law and Social Security Law \\ Dr. Isin Ulas Ertugrul Yilmazer, Research Assistant \\ Uludağ University, \\ Department of Labour Economics and Industrial Relations, Turkey
}

Doi:10.19044/esj.2019.v15n14p151 URL:http://dx.doi.org/10.19044/esj.2019.v15n14p151

\begin{abstract}
The right to work is a fundamental human right ensuring that every individual shall be able to continue their lives with a desired job and an income allowing the protection of human dignity. The right to work is directly related with the right to live of the working class that tries to live on their labor. Therefore, the right to work is the quest for a right based on life under a social order allowing every individual to have a job and income for continuing their lives in addition to protecting their dignity while allowing personal development and individual freedom. In this view, this study is based on the right to work which is a fundamental human right has been taken into consideration from the international human rights law perspective. Because of that firstly the concept of human rights and its historical development have been underlined. After then, it wants to take attention to emphasize of work right in concept of human rights. In this context, demand right to be employed, working right at a job which freely gained, the right to protection against the termination of labour contract and the right to use of freedom of association and union rights have been discussed.
\end{abstract}

Keywords: The right to work, Human right, Gain job freely, Right to be employed, job security, freedom of association, ECHR Decisions.

\section{INTRODUCTION}

The right to work is a fundamental human right ensuring that every individual shall be able to continue his or her life with a desired job and an income allowing the protection of human dignity. The right to work is directly related with the right to life of the working class that tries to live on their labor. Therefore, right to work is the quest for a right based on life under a social order allowing every individual to have a job and income for continuing their lives in addition to protecting their dignity while allowing personal development and individual freedom. 
Human rights are built on the concepts of "human" and "rights". They are based on material and spiritual development as well as the protection of human dignity. It is the sum of all indispensable, inviolable and inalienable fundamental rights and freedoms that people are subject to just because they are humans. The human rights propound a holism: they are universal, dependent, evolutionary, mutually related and holistic. There can be no hierarchy among human rights. It should be noted that the right to work is part of this holism. It is also a social and economic right that affects other human rights. There is a strong relationship between the right to work and the right to life. Protection against unemployment, leading a life with an income allowing the protection of human dignity and honor is an indispensable right for each individual.

Based on the aforementioned intent, the right to work, which is a fundamental human right has been taken into consideration from the international human rights law perspective in this study. Within this scope, the concept of human rights and its historical development have first been emphasized after the explaination of right to work. In addition, the place of the right to work as part of the human rights was underlined and the right to demand employment, the right to work at a freely gained job, the right to protection against the termination of labor contract and the right to benefit from union rights and freedoms have been discussed within the framework of the European Court of Human Rights (ECHR) decrees. In general, the study methodologically focused on rethinking right to work from the historical, theoretical and analytical spheres of scientific research.

\section{1) The Concept of Human Rights and Its Historical Development 1.1 The Concept of Human Rights}

The human rights express the fundamental rights and freedoms that humans gain from birth for being humans in addition to all the universal principles and rules that aim to protect and develop his/her personality (Adalet Bakanlığ [Ministry of Justice], 2011). It should be noted that the concept of human rights has always been one of the contemporary subjects in the fields of law and politics. Therefore, it is difficult to make a de facto definition of the human rights. Because the human rights issue is also a process that is still ongoing (Kaboğlu, 1991). However, the concept of human rights today brings to mind indispensable and inalienable rights that should be protected by the government order which are entitled to all humans regardless of their religion, race, color, gender, political thought, philosophical belief, religion, economic or social status and which humans have as a requirement for the protection of human dignity. In this framework, the rights that humans are entitled to just because they are humans lead us to the definition of human rights, whereas the human rights understanding that points out only the fundamental rights lead 
us to the definition of human rights in the narrow sense of the word. Regardless of how the concept of human rights is defined, they are the rights aiming to protect the financial and spiritual development of humans as well as human dignity which humans are entitled to just because they are humans. The word of "dignity" indicates the worth that demands certain forms of respect. The claim of human dignity is that simply being human makes one worthy or deserving of respect. And, human rights can only be understood to specify this form of respect -goods, services, opportunities, and protections which are owed to each personas a matter of rights- implied by this dignity (Donnelly, 2013). Hence, the human rights are universal and they are comprised of all inanviolable and inalienable rights that humans have as a requirement of human dignity.

It should be stated that the human rights have been built on the concepts of "human" and "rights". The concept of rights can be expressed differently according to various theoretical opinions. For instance, whereas the will theory defines rights as the will power provided to individuals by the legal order, interest theory defines rights as interests protected and recognized by the legal order. According to the mixed theory combining these two, right is defined as a benefit that is protected by law the use of which is left to the will of the subject of the right (Turhan, 2013). Regardless of the theory used for defining the rights, right is the foundation of law and every right brings with it the obligation for respect. However, it is not sufficient. There should be an obligation for authority, demand and respect to the subject of the right in order for a right to be meaningful. "Authority is being able to do what lies at the core of the right. Demand gives the authority to make a positive or negative demand to each right owner. Whereas respect means the desire to recognize the authority for benefiting from the right in general or with regard to a single individual and determining the respect as legitimate" (Turhan, 2013; Kaboğlu, 1991). It is a space for freedom and privilege provided to the individual against every authority regardless of whether the source of the right is based on national law or international agreements or whether it is based on social practice. In this regard, we are faced with new definitions of the concept of right when we consider the concept of right. It is possible to classify these under four different headings. The first is the ethical meaning and can be defined as carrying out certain actions and activities without harming others. The second is the political meaning and is comprised of the rights of citizenship as well as the rights of electing and being elected. The third is the legal meaning and can be defined as advocacy, allegation and and legal egalitarianism. Whereas the fourth is the economic meaning and comprised of the rights to own a business and career, acquisition of property and to do business. 
Therefore, human rights are the rights gained at birth and foresee the existence of the individual as a human being, his/her respectability and humane life. That is why, protection of human rights is accepted as one of the fundamental reasons for the existence of governments in democratic countries. Based on this intent, government as an authority has been limited and an area has been formed in which the government cannot intervene in various rights. Some classifications have been made regarding the position of the government against the human rights. These are classified as; distinctions made by taking into consideration negative-positive-active status rights, individual-collective rights distinction or the historicity of the acceptance of the rights (Turhan, 2013).

\subsection{Historical Development of Human Rights}

The first generation rights (Personal Freedoms and Political Rights) These rights that are defined as classical rights include personal freedom and political rights. These rights have been put forth by the thinkers of the $17^{\text {th }}$ and $18^{\text {th }}$ centuries. These rights have been put down in writing along with the American and French revolutions thus taken under protection. These rights have been gained as a result of the struggle of the bourgeoisie against aristocracy due to the fact that the bourgeoisie had no safety of life and property despite the fact that they were getting richer and that the aristocracy had all the authority. This is the reason why freedom, ownership, security and resistance against oppression have been originally expressed in the French Declaration of the Rights of Man and of the Citizen (FDRMC), 1789, and these are the rights to life and personal inviolability, personal freedom and security of person, freedom of thought and expression, freedom of religion and belief, inviolability of housing, right to ownership, right to equality, right to establish associations, right to assembly and protest, right to work, right to petition, right to electing and being elected, right to enter public service, right to an unbiased judge. The rights on personal and political freedom, called as first generation human rights were primarily outlined and detailed in International Covenant on Civil and Political Rights (ICCPR) (U.N., art 1-27).

The second generation rights (Social, Economic and Cultural Rights) second generation rights that are expressed as economic, social and cultural rights are those that enabled the transformation of the social state that puts the government under positive obligations regarding the use of the first generation rights into constitutional rights. These rights have emerged during the $19^{\text {th }}$ and $20^{\text {th }}$ centuries. They have emerged as a result of a reaction to a period in which masses of people with no freedom and struggling with poverty could not benefit from the first generation rights, whereas the bourgeoisie that had reached a limited wealth benefited from the freedom and rights to ownership provided by the first generation rights. The social poverty experienced during 
the $19^{\text {th }}$ century and the difficult conditions that the working class was in triggered the struggle of the working class for political and economic rights starting from the second half of the $19^{\text {th }}$ century. Demands for the right to electing and be elected, political rights, right to association, improvement of working conditions, creating job opportunities and the provision of social security have come into prominence (Kaboğlu, 1997). The second generation rights basically includes the right to work, the right to establish associations, the right to strike and bargain collectively, the right to participate in workplace administration, the right to rest, social security right, the right to free education, the right to participate in cultural life, the right to medical care, the right to food, the right to housing, rights related with special care and assistance to mothers, children, disabled, elderly as outlined in both International Covenant on Economic, Social and Cultural Rights (ICESCR) (U.N., art. 1-15) and European Social Charter (Revised) (Council of Europe, ETS 163). Generally, these rights are based on the ideas of equality and guaranteed access to essential social and economic goods, services and opportunities.

The third generation rights (Solidarity rights) These rights were put forth following the second world war. They are quite different from the classical and social rights, which refer to individual rights. Karel Vasak contended that there were third generation human rights based on the principle of solidarity, which directly points out group rights (Vasak, 1977). Thefore, the third generation of human rights can be identified as solidarity rights, which cannot be exerted only by an individual, but only by groups or collectivities of people. These rights directly refer to the rights of people to self determination, right to development, right to receive human assistance, right to peace, environment right, right to respect the joint estate of humanity, etc. In short, the third generation rights discourse redefines the relationships between human rights, individual, government and society. Multidimensionality and the protection of human dignity stand out during the restructuring of the human rights process (Kaboğlu, 1991). Carl Wellman (2000) states that realization and securing of first- and second-generation rights of individual human beings requires the introduction of greater solidarity into international law. The third generation rights are the rights, which put forth the prisority of common observance, cooperation and solidarity for the protection of all human rights, including first and second generation human rights.

These rights emerge as the participation rights of the citizens (Kaboğlu, 1991) and include an apprehension for a human social life. Demand of rights to both the individuals and the society as a whole is present. These are the rights, which require both the intervention of the state as well as the 
effective participation and effort of all individuals and groups for their actualization and protection.

The fourth generation rights (Protection Rights of the Individual Against the Abuse of Science) Fourth generation rights that emerged following the third generation rights are those that protect human dignity against the possibility of the abuse of scientific and technological developments. This gereration rights relates to genetic engineering ensuring the inviolability of individual rights and inavailability of human body in terms of development of medical sciences, of genetics. At this point, Adrian V. Cornescu (2009) mentions, "studying of human genome, genetic manipulation, in vitro fertilization, experiences with human embryos, euthanasia and eugenies are activities that can generate complicated legal issues, ethical, moral and even religious reason for what public opinion has led States to deal with regulation of these isues". The related recommendations of EU are the examples to show the way to member states adapting principles which will govern the relation between genetic engineering and human rights, in such a way that the right to life and dignity would be understood as a right over genetic characteristics of a person (Recommendations (EU) 934/1982; Recommendation (EU) 1046/1986).

\section{2) The Concept of Right to Work and The Position of Right to Work as a part of The Human Rights}

\subsection{The Concept of the Right to Work and its Legal Basis}

The right to work has an important place inherit to the human rights and freedoms since its definition requires considering the right to work as a fundamental human right. The right to work is closely related with the right to life of the working class ${ }^{1}$. "Therefore, it is essential that everyone should live in a social order which enables them to have a job and income that will allow them to continue their lives, protect their dignity and allow the development of their personality ${ }^{2}$. In this framework, the right to work can be defined as the right to work and earn an income allowing an income worth of human dignity for everyone with the power and desire to work" (Talas, 1991: 408-409). It should be noted that "the right to work is not limited to have a job. Work environment and conditions are complete this right; while also encompassing occupational safety right, right to demand work environments in accordance with work and health conditions, right to demand appropriate work times, right to fair wage, right to paid holiday, right to rest, right to leisure, right to demand work suited to age, strength and gender in addition to right to social security"

${ }^{1}$ Concept of working class does not only refer to wage labourer, but also refers to everyone who has to work for an income required for the livelihood of them and their family, as well.

${ }^{2}$ This might not be practically honored in every country, today. However, it is the ideal social concept. 
(Kaboğlu, 2010: 46). In addition, the right to work also encompasses the right to freely choose an occupation, fair work conditions, secure and healthy life, freedom of association, prohibition of discrimination and the right to protection against the termination of labor contract $\left(\mathrm{K}_{1} \operatorname{liçoğlu}{ }^{3}\right)$.

According to Article 23 of the Universal Declaration of Human Rights; "1-Everyone has the right to work, to free choice of employment, to just and favorable conditions of work and to protection against unemployment. 2Everyone, without any discrimination, has the right to equal pay for equal work. 3-Everyone who works has the right to just and favourable remuneration ensuring for himself and his family an existence worthy of human dignity, and supplemented, if necessary, by other means of social protection. 4-Everyone has the right to form and to join trade unions for the protection of his interests." According to European Social Charter under the right to work heading, the parties undertake; " 1 - to accept as one of their primary aims and responsibilities the achievement and maintenance of as high and stable a level of employment as possible, with a view to the attainment of full employment; 2- to protect effectively the right of the worker to earn his living in an occupation freely entered upon; 3-to establish or maintain free employment services for all workers; 4-to provide or promote appropriate vocational guidance, training and rehabilitation" (ETS 163, Art. 1). Article 24 of ESC (revised) gives the right to protection in cases of termination of employment. According to item 24 of ESC; "With a view to ensuring the effective exercise of the right of workers to protection in cases of termination of employment, the Parties undertake to recognise: a) the right of all workers not to have their employment terminated without valid reasons for such termination connected with their capacity or conduct or based on the operational requirements of the undertaking, establishment or service; b) the right of workers whose employment is terminated without a valid reason to adequate compensation or other appropriate relief. To this end the Parties undertake to ensure that a worker who considers that his employment has been terminated without a valid reason shall have the right to appeal to an impartial body" (ETS 163, Art. 24).

The right to work is not a principle with only a philosophical value but a right with legal obligations. The right to work is inevitable for the use of other human rights and is part of human dignity (Gülmez, 2014). It should be noted that the freedom and the right to work that is provided to all that are part of the human rights documents and constitutions are valid for workers as well as civil servants and other public officials. Undoubtedly, carrying out public service is also akin to exercising the right to work (Gülmez, 2014). The right

${ }^{3}$ Presentations of the Court of Human Rights (in Turkish), avaible from: http://www.anayasa.gov.tr/files/insan_haklari_mahkemesi/sunumlar/ym_4/KilicogluCalisma Hakki.pdf. 
to work is a right that is given to all citizens and foreigners living in a country at all times and in all circumstances regardless of age and gender differences. The special provisions regarding foreigners, women, children and young people are exceptional ${ }^{4}$. Because the right to work is a right for the protection of both natural and social status of the owner. It should be noted that personal rights are non-negotiable and non-hereditary rights. Therefore, the fact that this right is personal has two outcomes. One of these is that the individual is free to use this right or not. Whereas the other is that the work is carried out by the owner of the right in person (Demir, 2014).

\subsection{The Position of the Right to Work Among Human Rights}

The right to work is a fundamental human right (Eren, 2013). The right to work is a social and economic based right. The right to work is also a right that affects other rights. Therefore, there cannot be a hierarchy among human rights since they are mutually binded by integrity. Human rights put forth a situation as the rings of a chain that are equal and bound together. Just as a chain is no longer a chain when one of its rings is broken, the lack or negligence of one of the human rights affects the ring of rights as a whole. In this regard, the human rights make it obligatory that they are bound together just like the rings of a chain. This dependence is due to the fact that human rights is universal, mutually dependent, evolutionary, related and therefore holistic. This has been expressed in the decree by the United Nations Human Rights Council as follows: "... civic and political freedoms as well as economic, social and cultural rights are interconnected and interdependent ..., ...when deprived of economic, social and cultural rights, man does not represent the human person whom the Universal Decleration regards as the ideal of the free man..." (Section E of Resolution 421(v) of 4 December 1950). This has been expressed in the subsequent decrees by the United Nations General Council as well as other declarations for the understanding of human rights in this manner. The Vienna Declaration (1993) states that, "All human rights are universal, indivisible and interdependent and interrelated. The international community must treat human rights globally in a fair and equal manner, on the same footing, and with the same emphasis" (Art. 5). The principle of indivisibility accepted for human rights has also been expressed in the preamble of the Charter of Fundamental Rights of European Union. According to the preamble; "... the Union is founded on the indivisible, universal values of human dignity, freedom, equality and solidarity" (para. 2). It has been put forth in Additional Protocol to the European Convention on Human Rights that, "Economic and social rights inherent aspects of human

${ }^{4}$ The exceptions refer to protective provisions such as prohibition of women's night work or child labour. 
dignity and are clearly human rights, in the same way as civil and political rights. These two categories of rights are interdependent and cannot be dealt with differently" (EC Recommendation 1415/1999). Therefore, strongly emphasizing that there cannot be a hierarcy between human rights and that all rights complement one another.

In short, human dignity and honor lie at the heart of the human rights. Regardless of which right is eliminated, that right takes on the priority. Sometimes economic and social rights may take priority over civil and political rights. The difference between negative status rights and positive status rights is not very meaningful with regard to the human rights discourse. Categorizing human rights and handling them in a hierarchical manner is not considered to be reasonable in our day. With a holistic perspective, the human rights are dealt as parts of an interdependent, complementary and indivisible whole. To put it more clearly, economic and social rights will not mean anything without civil and political rights. Similarly, civil and political rights will be meaningless without economic and social rights (Kılıçkaya, 2017). Thus, the right to work which is one of the human rights is indispensible for the actualization of other rights and is accepted as an indivisible part of human dignity $^{5}$ that all members of humanity are entitled to from birth (Şen, 2013).

\section{Rights that are Extensions of the Right to Work \\ 3.1 The Right to Demand Employment}

European Court of Human Rights (ECHR) predicates its decrees regarding the right to work on the first article of the European Social Charter. According to ESC Article 1/1; the parties undertake "to accept as one of their primary aims and responsibilities the achievement and maintenance of as high and stable a level of employment as possible, with a view to the attainment of full employment" (ETS 163) thus placing an obligation on the parties to put into effect an employment policy that aims full employment. According to this regulation; it is an obligation for the governments that are parties to the ESC to put into effect an economy policy that targets full employment. In addition, this regulation also brings forth an "obligation to strive for full employment" to the governments (Kıliçkaya, 2017).

It is not a coincidence that the right to work is included in the human rights texts following the First World War. Indeed, unemployment, poverty and bad working conditions have led the governments to regulate certain

\footnotetext{
${ }^{5}$ Human dignity: It is directed towards the objective of free and conscious decisions of humans as well as their effectiveness on the environment as spiritual being. The principle of protecting human dignity provides humans with a right to a spiritual and social value and the right to demand respect for being human. Human dignity encompasses the personal value and independence of humans. It is indispensable for the moral and material integrity and development of humans. Hence, human dignity is untouchble (Gören, 2007).
} 
actions by way of common agreements at an international level. It is put forth in the preamble of the ILO that, "The League of Nations members will strive to provide fair and humane conditions of work and to sustain them." (Talas, 1991: 109). This effort is put forth in the ILO Constitution revised after the Second World War as a requirement for the fight against poverty, unemployment, guaranteeing a proper wage and humane working conditions, attainment of permanent world peace and the emotions of humanity and justice (ILO Cons., preamble). It is put forth in the Declaration of Philadelphia (1944) that, "poverty anywhere constitutes a danger to prosperity everywhere" (Art. $\mathrm{I} / \mathrm{c}$ ) and "the war against want requires to be carried on with unrelenting vigour within each nation" (Art. I/d). According to Article II(a), it is stated that; "all human beings, irrespective of race, creed or sex, have the right to pursue both their material well-being and their spiritual development in conditions of freedom and dignity, of economic security and equal opportunity" thus putting forth the relationship between material well-being and moral development as well as among economic security, freedom and dignity. It has been emphasized clearly that an individual without economic security shall not be able to attain material and moral development and that he/she shall not be able to protect his/her dignity and freedom. Taking this into consideration, "full employment and the raising of standards of living" in Article III/c and "the extension of social security measures to provide a basic income to all in need of such protection and comprehensive medical care" in clause $f$ have been considered as obligations of governments.

Indeed, the right to demand employment is a critical factor of the right to work. Because, "the right to work is also the right for everyone to work and have the required resources to continue their lives". Therefore, there is a strong relationship between the right to work and the right to life. Protection against unemployment, continuing one's life with an income protecting human dignity and honor is the fundamental and indispensable right of all human beings (Demir, 2014). Thus, the right to demand employment may be expressed as, "the right to carry out any activity worthy of human dignity that is bestowed to all by the government with minimum conditions of employment provided" (Şen, 2013). The right to work places an obligation on the government to ensure the development of employment opportunities and the taking of the required precautions. Based on this intent, governments should make it easier for job seekers to get a job, helping those who lost their jobs unwillingly and taking the precautions for creating certain obligatory jobs (Şen, 2013).

\subsection{The Right to Work at a Freely Gained Job}

The right to work or the right to work at a freely gained job implies the right of employees to sustain their lives at the job they have freely chosen in full freedom without any discriminative treatment or complicating obstacles. 
According to article 1(2) of ESC, the parties undertake to, "to protect effectively the right of the worker to earn his living in an occupation freely entered upon" (ETS 163). At this point, the two bases of the study may be put forth. One of these is the autonomy of will that is the freedom of contract. The other is the right to access. Autonomy of will means that the legal order will help the individuals to reach the legal results they desire, that it will recognize the wills of individuals shifting towards certain legal results as valid and that it will adopt to and secure the certain legal results that the will of individuals shift towards $\left(\right.$ Karagülmez $\left.^{6}\right)$. Whereas the right to access implies both the opportunities to have access to work as well as the right to benefit from education, vocational counseling and employment services put forth as stages towards the access to work. Indeed, according to article 1(3) of ESC, the parties undertake to; "to establish or maintain free employment services for all workers" whereas they undertake to; "provide or promote appropriate vocational guidance, training and rehabilitation” (ETS 163, art. 1(3)).

As can be seen in the decrees by the European Social Rights Committee and ECHR, freedom to work "includes all instances that might prevent the individual to take part in an occupational relationship with his/her own will or to freely choose a job." (Kılıçkaya, 2017). European Social Rights Committee relates the freedom to work with the prohibition of discrimination in work life. The committee sees discriminating applications as a significant obstacle in the use of the right to access of work life (ECSR, 2008). Whereas ECHR evaluates forced labor ${ }^{7}$ in its decrees as the failure to protect the privacy of private life as well as the breach of the freedom to work (Kılıçkaya, 2017).

In its SILIADIN v. France (dec.) no.7331601, 26.07.2005, ECHR confiscated the passport of a woman from Togo named Sivu-Akofa Siliadin brought to France by a French citizen of Togo origin at the age of 15 in 1994 in order to receive immigrant status thereby making her a servant working without pay. In addition, she was loaned to friends for assisting housework and taking care of small children. Siliadin continued to work without pay until

\footnotetext{
${ }^{6}$ Article is published on the official web site of Supreme Court of Turkey. Avaible from: http://www.anayasa.gov.tr/files/insan_haklari_mahkemesi/sunumlar/ym_2/KaragulmezAY MveSosyalSart.doc

${ }^{7}$ ECHR defines forced labor in accordance with the description in convention 29 of ILO. In this framework, the term forced labor or compulsory labor has been defined in the ILO Convention 29, accepted on June 28, 1930 which went into effect on May 1, 1932 the last provisions of which were changed in 1946. According to the article 2(1) of this convention, "forced labor or compulsory labor" means "... all work or service which is exacted from any person under the menace of any penalty and for which the said person has not offered himself voluntarily". Accordingly, in order for an action to be considered as forced or compulsory labor: i) it should be carried out in defiance of the personal will of the individual; ii) the obligation to carry out the work should be "unjust" or "oppressive" or that it should lead to undesired burdens if not carried out (Doğru-Nalbant et al., 2012).
} 
1998. In July 1998, she mentioned her status to a neighbor she trusted. The situation of Siliadin was brought to trial when she applied to the Modern Slavery Committee. Claims for benefiting from an individual without pay and putting individuals to work under conditions that are not in accordance with human dignity were charged against those who put Siliadin to work in accordance with the items 225-13 and 225-14 of the French Penal Code. The trial was carried over to the court of appeal from the district court and from the court of appeal to the Versaille Superior Court. Versaille Superior Court reached a decree on the $15^{\text {th }}$ of May 2003 thus filing a non-pecuniary damage worth 15.245 Euro for putting an unprotected and dependent individual to unpaid work, however concluded that the agreement and conditions of living cannot be considered to be incompatible with human dignity. In response, Siliadin applied to the ECHR on the grounds of the breach of ECHR (European Convention on Human Rights) article 4 (Prohibition of slavery and servitude). ECHR evaluated the situation of Siliadin as servitude. According to the court, "servitude" should be evaluated the obligation of an individual to serve under pressure and is related with the concept of "slavery" (Doğru-Nalban et al, 2012). In addition, the court also put forth as part of the same decree that item 4 of the convention is one of the fundamental values that make up the democratic societies forming the European Council, that the member countries of the European Council are obliged to consider slavery and servitude as crimes and that the government has a positive liability against forced labor.

In the Özpinar v. Turkey (dec.), no. 20999/04, 19.10.2010 by the ECHR, the court examined, within the scope of article 8 , the dismissal of a female judge in Turkey as a result of an inspector investigation due to the clothing, make up and the individuals befriended in the private life of the applicant thus concluding that the right to respect for private life has been breached. In this decree, the Court first reminded the principles regarding the scope of the right to respect for private life. According to the Court, the concept of "private life" secured by item 8 of the convention is a wide concept and that it includes the right to act in "social private life" in which the individual has the opportunity to develop his/her social identity. Therefore, judicial opinions regarding the issue accept the establishing of relations with other people for establishing and developing relations with others. There is no reason for accepting that private life does not include occupational activities. Limitations on work life may be considered to be within the scope of item 8 of the convention in case they occur when the individual is trying to form his/her social identity by way of establishing relations with others. Majority of the people find the opportunity to strengthen their bonds with the outside world in their professional lives. In this case, the Court did not observe that the applicant has been dismissed solely for professional reasons. According to the Court, disciplinary investigation and the decision for dismissal are not only related with the actions and 
relations of the applicant in her professional life but are also directly related with her actions and relations in her private life as well. Moreover, criticisms directed at the applicant during the investigation may endanger the dignity of the applicant. The right of the individual to protect his/her dignity is part of the right to respect to private life included in item 8 of the convention. In this respect, the process of the investigation on professional and private lives along with the means of dismissal resulted in the formation of the opinion that the right to respect for private life has been breached. Taking into consideration the conditions of the incident, the Court concluded that a just balance should be attained in a democratic society between the right to respect for private life which is one of the fundamental rights of the individual and the legitimate interests put forth in clause $8(2)$ of the convention and that the intervention to the private life of the plaintiff is not measured in accordance with the legitimate objective followed therein (Doğru-Nalbant et al, 2013).

ECHR has sought for a reasonable balance between the life style and behaviors of the employer and the right to govern of the employer in many of its decrees regarding the style of life. It has been put forth that the life area of the employer including the family life, emotional and sexual lives of the employee comprise the most confidential aspect of his/her personal life and that the living area of the employee is in principal beyond the scope of the interest and the right to govern of the employer (Çetin, 2015; Köksal, 2015).

\subsection{The Right to Protection Against the Termination of Labor Contract (Job Security)}

The right of the worker to protect his/her job is important for the protection of both his/her benefits as well as the protection of the benefits of society (Çelik, Caniklioğlu \& Canbolat, 2016). When one loses their job, especially when it is their only means of income, this economic circumstance does not only affect their level of welfare, but also result in social problems with adverse effects on social life (Süzek, 2013). Therefore, job security is the protection of an employee against the termination of his/her right to work. The objective of job security law is to prevent the "arbitrary" termination by the employer of the job relationship (service relationship) without a "reasonable, valid or acceptable" reason. It aims to provide the contiuity of the job relationship by placing various obstacles to the unilateral cancellation will of the employer. Thus, the right to work is protected by placing various enforcements against arbitrary cancellation such as compensation or reemployment. Because job security is an indispensable right for a dignified life due to many issues in the work life such as the anxieties of the employee for losing his/her job, not feeling secure of one's future and the anxiety of losing his/her wage which is the means of livelihood for him/her as well as his/her family (Candan, 2001). That is why, job security is considered in the 
conventions and advisory jurisdictions by ILO in addition to the international human rights documents as an important assurance for the protection of the right to work. According to the ILO Convention 158, "The employment of a worker shall not be terminated unless there is a valid reason for such termination connected with the capacity or conduct of the worker or based on the operational requirements of the undertaking, establishment or service" (Art. 4), "The employment of a worker shall not be terminated for reasons related to the worker's conduct or performance before he is provided an opportunity to defend himself against the allegations made, unless the employer cannot reasonably be expected to provide this opportunity" (Art. 7). Similarly, according to ESC, the parties undertake to recognize; "a) the right of all workers not to have their employment terminated without valid reasons for such termination connected with their capacity or conduct or based on the operational requirements of the undertaking, establishment or service, $b$ ) the right of workers whose employment is terminated without a valid reason to adequate compensation or other appropriate relief" and the parties undertake to ensure "...that a worker who considers that his employment has been terminated without a valid reason shall have the right to appeal to an impartial body" (ETS/163), art. 24)

According to Aras (2015), the protection of the job has important consequences for himself/herself, his/her family and the protection of his/her personal rights since there is a strong relationship between the protection of the job of a worker and the sustainment of a dignified life. Taking this into consideration, ECHR considers in its decrees the prevention of the right to work as an intervention to private life since it poses a significant obstacle in the attainment of the livelihood of the family (Kılıçkaya, 2017). It should be noted that ECHR has a wide range of judicial opinions against unjust termination. The rights in EDHR are interpreted according to how the incident took place. In some cases, unjust terminations are evaluated within the scope of the right to freedom of expression, whereas in others it is evaluated within the scope of the right to respect for private life. It is quite difficult to categorize the related decrees according to the subject. However, it is generally directed towards issues in which an individual is laid off for using a right protected by the EDHR or cases when termination breaches the right to respect for private life of the individual (K1lıçkaya, 2017).

In its Vallauri v. Italy (dec.), no. 39128/05, 20.10.2009, ECHR evaluated the termination of the contract within the scope of ECHR item 10. In this case, the contract of the applicant working at a sectarian university was not renewed due to the fact that the applicant did not comply with the opinions of the university and because the applicant had different opinions. The applicant put forth that the decision declared without showing any justification and without any mutual discussion has resulted in the breach of the freedom of expression. 
The applicant also filed a complaint stating that the possibility of objecting via local courts has decreased since the decision of the faculty board was not based on any justification and that the faculty board came to a conclusion based on community decision and not as a result of a mutual discussion. In this case, the court declared that item 10 (freedom of expression) of the convention has been breached. The court reached a conclusion that the benefits that will be obtained from an education based on Catholic doctrines cannot outweigh the procedural assurances provided to the applicant by way of article 10 . The court also put forth that the intervention on the freedom of expression of the applicant is not "necessary in a democratic society". Based on the same justifications, the court also gave a ruling that article 6 (1) of the ECHR which arranges the right to fair trial has also been breached since the applicant has not been able to benefit from the right to effective trial. In this case, both the freedom of expression and the right to fair trial were used as justifications by ECHR.

In its Boyraz v. Turkey (dec.) no. 61960/08, 02.12.2014 (finally 02.03.2015), ECHR gave a ruling which states that article 8 and 14 of the convention have been breached as a result of the dismissal due to gender. The case is related with the dismissal of the applicant from her job at an electric company because of her gender. The applicant put forth that she worked for about three years at this workplace as a security officer before being laid off, that she is not a male and that she has not completed her military obligation putting forth that she has been laid off because of her gender. In addition, she also asserted that the decrees about her were "discriminatory" 8 with regard to gender and that the administrative actions taken regarding her dismissal took much longer than necessary. In this case, the court alleged that different behaviors for different genders may not be justified just because security officers may meed to work at night shifts or that they may need to work in rural regions or that they may have to resort to the use of weapons and physical force and that the dismissal of the applicant was due to the decrees by the administrative courts in Turkey rather than the possibility of her failing to take on such risks and responsibilities. The court stated that the institution in question has not presented any evidence indicating that the applicant has failed to fulfill her duties. The court reached a conclusion that the administrative courts have not based their decrees only male staff may work as security officers at a government institution on reasonable grounds. As a result, the court gave a ruling indicating that article 8 of the convention (prohibition of discrimination of article 14 interrelated with the right to private life and family

\footnotetext{
${ }^{8}$ According to ECHR, discrimination is a treatment that is not based on an objective or reasonable justification according to article 14 of the contract meaning that it has no legitimate objective with no reasonable proportion between the used tool and the objective (DoğruNalbant, 2012).
} 
life) has been breached. In addition, the court also gave a ruling stating that article 6(1) (the right to a fair and public hearing within a reasonable time by an independent and impartial tribunal established by law) of the convention has also been breached.

\subsection{The Right to Benefit from Union Rights and Freedoms}

The right to and freedom of association play an important role in the protection of the right to work. The fact that the rights and benefits arising from the work relation due to a collective agreement in the name of a group of workers which may be rearranged increases the effect of the union rights on the right to work. For instance, ESC put forth in article 4 arranging the right to a fair remuneration that collective agreements are one of the means to determine the remuneration such as will give the workers and their families a decent standard of living (ETS/163, art. 4, para. 4). Therefore, union rights and freedoms play a determining role in the rearrangement of rights such as wage, working conditions, job security and arrangement arising from the work relation. Therefore, union rights and freedoms play a determining role in the protection of employment and work relations (Skenderaj, 2015) from which crucial arrangements such as wage, working conditions and job security arise.

What should be understood from union rights and freedoms is the right of the individual to establish trade unions, be a member to a union of his/her preference, taken into consideration, protection of professional benefits, making a collective agreement and carrying out activities as an organized group for the protection of the rights and benefits of the group members (Doğru-Nalbant, 2013). The independence of the members of the group against their organization and the independence of the organization against the government is essential for the protection of the principle of the freedom of establishing trade unions (Kutal, 1962). Sur (2017) refers ESC, ECHR and ECHR decrees as the bases of the union right and freedom in international human rights law. According to ESC article 6(1), the parties; "With a view to ensuring or promoting the freedom of workers and employers to form local, national or international organisations for the protection of their economic and social interests and to join those organisations, the Parties undertake that national law shall not be such as to impair, nor shall it be so applied as to impair, this freedom" (ETS/163). According to article 6, the parties; "With a view to ensuring the effective exercise of the right to bargain collectively, the Parties undertake: 1. to promote joint consultation between workers and employers; 2. to promote, where necessary and appropriate, machinery for voluntary negotiations between employers or employers' organisations and workers' organisations, with a view to the regulation of terms and conditions of employment by means of collective agreements; 3 . to promote the establishment and use of appropriate machinery for conciliation and voluntary 
arbitration for the settlement of labour disputes and recognize; 4. the right of workers and employers to collective action in cases of conflicts of interest, including the right to strike, subject to obligations that might arise out of collective agreements previously entered into". According to the ILO Convention, "Workers and employers, without distinction whatsoever, shall have the right to 2 . establish and, subject only to the rules of the organisation concerned, to join organisations of their own choosing without previous authorisation" (No. 87, Art. 6). According to article 11(1) of ECHR; "Everyone has the right to freedom of peaceful assembly and to freedom of association with others, including the right to form and to join trade unions for the protection of his interests". As can be clearly seen from the arrangements above, the right and freedom of association is a right secured by the international human rights documents and this right has been entitled to all employees and employers.

ECHR has issued many decrees for the protection of the union right and freedom within the framework of articles 10 and 11 of the related convention. By its decrees, ECHR evaluates international human rights law as a whole. It especially takes into account the decrees issued by the European Social Rights Committee (related with the articles 5 and 6 of ETS/163) and the Freedom of Association Committee of ILO (related with the article 87 on the protection of the freedom of association and union rights). According to ECHR; freedom of assembly and association in ECHR article 11(11) is a means and unique aspect of the freedom of association (National Union of Belgium Police v. Belgium (dec) no. 4464/70, 27.10.1975)). Each freedom also includes a certain aspect of choice when being used. It should be kept in mind that one of the objectives of the freedom of association is the right to protection of the personal opinions secured by way of items 9 and 10 of the convention. This protection can be provided by way of securing negative freedom of association and the positive freedom of association together (ECHR, Chasagnou and the others v. France (dec.) nos. 25088/94, 28331/95 and 28443/95, 29.04.1999). In this context, the concept of personal autonomy is the principle underlying the interpretation of the securities in the convention. This concept is an important consequence of the right to selection of the individual accepted implicitly in item 11 as well as an important element that puts forth the negative aspect of this item (ECHR, Sorensen and Rasmussen v., Danimark (Dec.) nos: 52562/99 and 52620/99, 11.01.2006). In addition, article 11 of the convention also includes the principle of the protection of the Professional benefits of the union members by way of common action within the union. Contractarian governments should allow common action and should allow for the course and development of the action. The phrase "for the protection of benefits" in article 11(1) of the convention secures the freedom of the union members to protect their professional benefits by way of union 
activities. Contractarian governments should both allow these union activities as well as enable them. Hence, unions have the right to listen to the opinion of the union for the protection of the benefits of their members (National Union of Belgium Police v. Belgium (dec) no. 4464/70, 27.10.1975)).

Demir and Baykara Decree among the decrees by ECHR is a very important and historical decree for the freedom of association and the right to collective agreement. In its Demir and Baykara v.Turkey (dec.) no. 34503/97, 12.11.2008, ECHR interpreted the union right arranged in article 11 of ECHR based on the scope of the union right and freedom arranged in ILO convention 87 and articles 5 and 6 of ESC. When resorting to this method of interpretation, ECHR put forth two fundamental justifications. One of these is that effort to protect ECHR as a living norm, whereas the other is to consider the international human rights law as a whole. In this incident that was the subject of the decree by ECHR, the applicant K. Demir is a member of the Tüm BelSen union, whereas V. Baykara is the chairman of this union. Tüm Bel Sen union was established in 1990 by civil servants that are subject to the Law of Civil Servants numbered 657. A two year collective agreement was signed in 1993 between Tüm Bel-Sen and the Gaziantep Metropolitan Municipality that would go into effect starting from January $1^{\text {st }}, 1993$. This agreement covers the working conditions and wage related issues related with the Gaziantep Metropolitan Municipality. Gaziantep Metropolitan Municipality put forth that it will not put into practice the aforementioned collective agreement. In response, the applicant filed a complaint on June 17, 1993 at the Gaziantep Civil Court of First Instance as the representative of the union for ensuring that the agreement is put into practice. The court acknowledged the union as right. However, the Supreme Court overruled the decree by the court of first instance stating that there is no prohibition for the civil servants to establish a trade union but that according to the positive law in practice, they have no authority to sign a collective business agreement. Court of first instance insisted upon its first decree indicating that this deficiency can be overcome in the light of the ILO Constitution and agreements approved by Turkey. However, the Supreme Court overruled this decree of the court of first instance once again. As a result of the finalization of the means of internal law, the applicants carried the case over to the ECHR. In this case, ECHR gave a ruling which expanded the scope of the union right arranged in item 11 of ECHR. The court rejected the limitations that would touch upon the essence of the right to freedom of association. With this decree, the court gave a ruling not according to the letter of the agreement but by taking into consideration the current legal and political developments. ECHR has always taken important steps for the institutionalization of the developmental interpretation method it applied. With this decree, ECHR used the related items of the European Council Social Charter without taking into consideration whether a 
government has placed reservations on them or not while also indicating that the charter is not the only foundation for the interpretation of the rights and freedoms in the ECHR and handled the international human rights norms as a whole without considering the approval of governments. The court also included the decrees by ILO and UN contracts as well as decrees by auditing bodies when examining this disagreement (ECHR, Case Of Demir Baykara v. Turkey (dec.) no. 34503/97, 12.11.2008).

\section{CONCLUSION}

The right to work is a fundamental human right. Protection of human dignity is a principle in the right to work. The right to work has been built on the concepts of "human" and "right" as is the case for other human rights. The right to work is a right that affects other human rights since it is a socioeconomic based right. It should be noted that one who is struggling with the anxieties of "earning one's bread" cannot be expected to benefit from the freedom of thought with a political consciousness. Therefore, "civil and political rights are interrelated and interdependent with economic, social and cultural rights" as has been put forth in the decree numbered 421(v) by UN Human Rights Provincial Council dated 1950. The totality of the rights is indispensable for the freedom of the individual.

On the other hand, the rights that are the extensions should also be secured in order to secure the right to work. One of these is the right to demand employment. The right to demand employment is an important aspect of the right to work. The right to demand employment intends that everyone has an income through work that will allow them to continue their lives. Protection against unemployment, living in protection of human dignity and honor form the basis of this right. The second is the right to work. The right to work is the sustainment of the life of an individual in full freedom at a freely gained job without being subject to any discriminative treatment or complicating obstacle. Autonomy of will and the right to access to work lie at the heart of this right. Autonomy of will implies the freedom to make agreements, whereas the right to access to work implies the opportunities for finding a job such as vocational counseling and employment services. The third is the right to protection against the termination of the labor contract. The protection of the employee against the termination of the labor contract is the protection of the right to work. What is meant by the protection of the employee against the termination of the labor contract is the prevention of the "arbitrary" termination by the employer of the job relationship without a "reasonable, valid or acceptable" reason. Thus, it is the elimination of anxieties of the employee for losing his/her job and the anxiety of losing his/her wage which is the means of livelihood for him/her as well as his/her family. Whereas the fourth is the protection of the right to benefit from union rights and freedoms. 
The right to association and negotiation, making a (Cornescu, 2009)contract, strike and lockout play an important role in the protection of the right to work of the employer. The impact of the collective will that emerges within the framework of the rearrangement of the working conditions so as to protect human dignity reshapes the working relationships for the protection of the economic and social benefits of the employees. Especially, both the welfare levels of employees are increased while humanizing the working conditions further by way of collective agreements.

In short, the right to work is a socio-economic based fundamental human right. The right to work is a right that affects other rights. Protection of the dignity of the individual constitutes the basis of the right to work.

\section{References:}

1. Adalet Bakanligi. (2011). Adalet Bakanllğg Personeli Görevde Yükselme Ĕgitimi Ders Notları: Insan Haklarl. Retrived from Adalet Bakanlığ $\quad$ Eğitim Dairesi Başkanlığ 1 website: http://www.edb.adalet.gov.tr/duyuruarsiv/2015/iimnotlar/insanhaklari .pdf.

2. Aras, T. (2015). İş Güvencesinden Yararlanmanın Koşulları ve Emredicilik. TBB Dergisi , 2015, 119, 429-456. Retrived from: http://tbbdergisi.barobirlik.org.tr/m2015-119-1501.

3. United Nations General Assembly (1966, 12 16). International Covenant on Civil and Political Rights. 1 11, 2019 tarihinde Unites Nations, Treaty Series, 999. Retrived from UN website: https://reaties.un.org/doc/publication/unts/volume\%20999/volume999-i-14668-english.pdf.

4. Baboğlu, İ. Ö. (1991). Dayanışma Haklarının Hukuksal Değeri (Soyut Talepler mi, İnsan Hakları mı?). Insan Haklarl Yıllı̆̆ , 13, 1, 37-48.

5. Candan, M. A. (2001). Işs Güvencesi Talebinin Klsa Tarihi. Retrived from BİANET website: https://bianet.org/bianet/siyaset/3307-isguvencesi-talebinin-kisa-tarihi.

6. Cornescu, A. V. (2009). The Generation of Human Rights. Days of Law. Masaryk University. Retrived from: https://www.law.muni.cz/sborniky/dny_prava_2009/files/prispevky/t vorba_prava/Cornescu_Adrian_Vasile.pdf.

7. Council of Europe. (1996). European Social Charter (Revised). ETS 163. Retrived from: https://www.refworld.org/docid/3ae6b3678.html.

8. Çelik, N., Caniklioğlu, N., \& Canbolat, T. (2016). İs Hukuku Dersleri (29 ed). İstanbul: Beta.

9. Çetin, E. (2015). Çalışanların Özel ve Aile Yaşamına Saygı, Düşünce ve İfade Özgürlükleri. A. Güzel, D. Ugan-Çatalkaya, \& H. Heper, In İş Hukukunda Güncel Sorunlar (s. 75-136). Ankara, Türkiye: Seçkin. 
10. Demir, F. (2014). Çalışma Hakkı Kavramı ve Hukuki Niteliği. VI. Sosyal Insan Hakları Ulusal Sempozyumu . 119. Retrived from: Petrolİş. http://www.sosyalhaklar.net/2014/bildiriler/demir.pdf.

11. Doğru, O., \& Nalbant, A. (2011). Insan Hakları Avrupa Sözleşmesi: Açıklama ve Önemli Kararlar (Cilt I). Ankara: Seçkin.

12. Doğru, O., \& Nalbant, A. (2012). Insan Hakları Avrupa Sözleşmesi: Açıklama ve Önemli Kararlar (Cilt II). Ankara: Seçkin.

13. Donnelly, J. (2013). Universal Human Rights in Theory and Practice. Ithaca, New York: Cornell University.

14. EC Parliamentary Assembly. (1999). Additional protocol to the European Convention on Human Rights concerning fundamental social rights, Recommendation 1415/1999. Retrived from Council of Europe website: http://assembly.coe.int/nw/xml/XRef/XrefXML2HTML-en.asp?fileid=16718\&lang=en.

15. ECHR. (2010, 10 19). Case Özpinar v. Turkey (Appl. No. 20999/04). Retrived from Council of Europe website: https://hudoc.echr.coe.int/app/conversion/pdf/?library=ECHR\&id=00 3-3308450-3696102\&filename=003-3308450-3696102.pdf.

16. ECHR. (1999, 4 29). Case of Chassagnou and others v. FRANCE (Appl. nos. 25088/94, 28331/95 and 28443/95). Retrived from Council of Europe website: http://www.menschenrechte.ac.at/orig/99_3/Chassagnou.pdf.

17. ECHR. (2008, 11 12). Case of Demir and Baykara v. Turkey (Appl. No. 34503/97). Retrived from Council of Europe website: https://hudoc.echr.coe.int/eng\#\{"itemid":["001-89558"]\}.

18. ECHR. (2014, 12 2). Case of Emel Boyraz v. Turkey (application no. 61960/08). Retrived from Council of Europe website: https://hudoc.echr.coe.int/app/conversion/pdf/?library=ECHR\&id=00 3-4951617-6065162\&filename=003-4951617-6065162.pdf.

19. ECHR. (2009, 10 20). Case of Lombardi Vallauri v./Italy (Appl. No. 39128/05). Retrived from Council of Europe website: https://hudoc.echr.coe.int/app/conversion/pdf/?library=ECHR\&id=00 3-2900937-3189238\&filename=003-2900937-3189238.pdf.

20. ECHR. (1975, 10 27). Case of National Union of Belgium Police v. Belgium (Appl. No. 4464/70). Retrived from Council of Europe website: http://www.legislationline.org/documents/id/18463.

21. ECHR. (2015, 6 26). Case of Siliadin v. France (Application no. 73316/01). Retrived from Council of Europe website: http://hudoc.echr.coe.int/app/conversion/pdf/?library=ECHR\&id=001 -69891\&filename=001-69891.pdf\&TID=wektxxvmzq.

22. ECHR. (2006, 111$)$. Case of Sorensen \& Rasmussen v. Denmark (Appl nos. 52562/99 and 52620/99). Retrived from Council of Europe 
website:

https://hudoc.echr.coe.int/app/conversion/pdf/?library=ECHR\&id=00 3-1553007-1625438\&filename=003-1553007-1625438.pdf.

23. Eren, B. (2013). Anayasal Çerçevede Türkiye'de Çalışma Hakkı. ÇSGB Çalışma Dünyası Dergisi , 1 (2), 66-84.

24. International Labour Organization, Decleration of Philadelphia. Retrived from ILO website:

https://www.ilo.org/legacy/english/inwork/cb-policyguide/declarationofPhiladelphia1944.pdf.

25. European Union. (2012, 10 26). EU Charter of Fundamental Rights. Retrived from European Cmission website: https://www.refworld.org/docid/3ae6b3b70.html.

26. Gören, Z. (2007). Avrupa Birliği Temel Haklar Şartının Ana İlkesi: Dokunulmaz İnsan Onuru, . İstanbul Ticaret Üniversitesi Sosyal Bilimler Dergisi , 12, 2, 21-37. Retrived from: https://core.ac.uk/download/pdf/53032000.pdf.

27. Gülmez, M. (2014). Çalışma Özgürlüğü ve Hakkı Açısından Emeğin Evrimi: Ulusal ve Ulusalüstü Hukuksal Boyutlar Üzerine Düşünceler. VI. Sosyal Insan Haklarl Sempozyumu. 119. Retrived from: https://www.petrol-is.org.tr/sites/default/files/tum-dokumanbaski.pdf.

28. International Labour Organization. (1919, 6 28). Constitution. Retrived from ILO website: https://www.ilo.org/dyn/normlex/en/f?p=1000:62:0::NO:62:P62_LIS T_ENTRIE_ID:2453907:NO.

29. International Labour Organization. (1948, 7 9). Freedom of Association and Protection of the Right to Organise Convention No: 87. Retrived from ILO website: https://www.ilo.org/dyn/normlex/en/f?p=NORMLEXPUB:12100:0:: NO::P12100_INSTRUMENT_ID:312232.

30. International Labour Organization. (1944, 5 10). ILO Decleration of Philadelphia. Retrived from ILO website: http://www.ilo.org/legacy/english/inwork/cb-policyguide/declarationofPhiladelphia1944.pdf.

31. International Labour Organization. (1982, 6 22). Termination of Employment Convention No: 158. Retrived from ILO website: https://www.ilo.org/dyn/normlex/en/f?p=NORMLEXPUB:12100:0:: NO::P12100_ILO_CODE:C158.

32. Köksal, D. (2015). AİHM'in Sosyal Haklara Bakışı ve Uyguladığı Yorum Metodu. A. Güzel, D. U. Çatalkaya, \& H. Heper, In Işs Hukukunda Güncel Sorunlar 5 (55-70). İstanbul: Şeçkin. 
33. Kılıçkaya, Z. (2016). Avrupa İnsan Hakları Mahkemesi Kararları Işığında Anayasa Mahkemesi'nin Bireysel Başvuru İncelemelerinde Çalışma Hakkı. Dokuz Eylül Üniversitesi Hukuk Fakültesi Dergisi , $18,2, \quad 127-165$. Retrived from: http://hukuk.deu.edu.tr/wpcontent/uploads/2017/04/ZEYNEP-KILICKAYA.pdf.

34. Kılıçoğlu, M. Çalışma Hakkı Kapsamında İş Güvencesi. Retrived from Anayasa Mahkemesi website: http://www.anayasa.gov.tr/files/insan_haklari_mahkemesi/sunumlar/ ym_4/KilicogluCalismaHakki.pdf.

35. Kaboğlu, İ. (1997). Çağdaş Toplum Değerleri: Insan Haklart (Cilt 11). İstanbul: Çağdaş Yaşamı Destekleme Derneği.

36. Kaboğlu, İ. İnsan Haklarının Gelişmeci Özelliği ve Anayasa Yargısı (Insan Haklarl Evrensel Bildirgesinden Günümüze). Retrived from Anayasa Mahkemesi website: http://www.anayasa.gov.tr/files/pdf/anayasa_yargisi/anyarg9/kaboglu .pdf.

37. Kaboğlu, İ. (2010). Anayasada Sosyak Haklar: Alanı ve Sınırları. Retrived from: http://www.sosyalhaklar.net/2010/bildiri/kaboglu.pdf.

38. Karagülmez, A. (tarih yok). Anayasa Mahkemesi ve Avrupa Sosyal Şartı. Retrived from Anayasa Mahkemesi website: http://www.anayasa.gov.tr/files/insan_haklari_mahkemesi/sunumlar/ ym_2/KaragulmezAYMveSosyalSart.doc.

39. Kutal, M. (1962). Sendika Hürriyeti. Sosyal Siyaset Konferansları 13. Kitap. 941, 99-116. İstanbul: İstanbul Üniversitesi.

40. Council of Europe, Parliamentary Assembly. (1986, 9 24). Recommendation 1046/1986. Retrived from COE website: http://assembly.coe.int/nw/xml/XRef/Xref-DocDetailsen.asp?FileID $=15080 \&$ lang=en.

41. Council of Europe, Parliamentary Assembly. (1982, 1 26). Recommendation 934/1982. Retrived from COE website: http://assembly.coe.int/nw/xml/XRef/Xref-DocDetailsEN.asp?FileID $=14968 \&$ lang=EN.

42. Skenderaj, M. (2015). Protection of Freedoms through Employment Relations and Human Rights and Rule of Law. Freedom to Work -\&The Right to Work, European Scientific Journal, 11, 7, 58-65. Retrived from: https://eujournal.org/index.php/esj/article/view/5305.

43. Süzek, S. (2013). İş Hukuku. İstanbul: Beta.

44. Sur, M. (2017). Iş̧ Hukukunda Toplu İlişkiler. Ankara: Turhan.

45. Şen, M. (2013). İnsan Hakları Bağlamında Çalışma Hakkı. MÜHFD, II (2), 13-37.

46. Şirin, T. (2014). Bir İhtimal Daha Var, O da Ölmek mi Dersin? "Sosyal İnsan Haklarının Anayasa Şikayeti Yoluyla Dava Edilebilirliği Lehine 
Tezler ve Öneriler". Sosyal İnsan HaklarıUlusal Sempozyumu VI. 119, 341-366. İstanbuş: Petrol-İş. Retrived from: http://www.sosyalhaklar.net/2014/bildiriler/sirin.pdf.

47. Talas, C. (1991). Çalışma Hakları ve Türkiyede'ki Durum. $A \ddot{U} S B F D$, $46 \quad, \quad 1-2, \quad 407-421 . \quad$ Retrived from: http://dergipark.gov.tr/download/article-file/38234.

48. Turhan, A. (2013). İnsan Hakları Kuşakları Arasındaki Tamamlayıcılık İlişkisi. İnönü Üniversitesi Hukuk Fakültesi Dergisi , 4, 2, 357-378. Retrived from: http://dergipark.gov.tr/download/articlefile/208297.

49. United Nations General Assembly. (1950, 12 4). Draft International Covenant on Human rights and measures of implementation: future work of the Commission on Human Rights Resolution 421(V). Retrived from UN website: https://www.refworld.org/docid/3b00f07b58.html.

50. United Nations General Assembly. (1993, 7 12). Vienna Declaration and Programme of Action. Retrived from UN website: https://www.refworld.org/docid/3ae6b39ec.html.

51. Vasak, K. (1977). A Thirty Year Struggle: The Sustained Efforts to Give Force of Law to the Universal Decleration on Human Rights. UNESCO Courier , XXX, II, 29-36. Retrived from UNESCO website: https://unesdoc.unesco.org/ark:/48223/pf0000048063.

52. Wellman, C. (2000). Solidarity, the Individual and Human Rights. Human Rights Quarterly , 22, 3, 639-657. Retrived from: https://www.jstor.org/stable/4489297?seq=1\#page_scan_tab_content s. 